\title{
$T B X 15$ rs98422, DNM3 rs1011731, RAD51B rs8017304, and rs2588809 Gene Polymorphisms and Associations With Pituitary Adenoma
}

\author{
GABIJA JUKNYTE் ${ }^{1}$, INGA LAURINAITYTE் ${ }^{1}$, ALVITA VILKEVIČIŪTE் ${ }^{2}$, GRETA GEDVILAITE் ${ }^{2}$, \\ BRIGITA GLEBAUSKIENE ${ }^{2}$, LORESA KRIAUČIŪNIENE ${ }^{2}$ and RASA LIUTKEVIČIENÉ2 ${ }^{2}$ \\ ${ }^{1}$ Medical Academy, Lithuanian University of Health Sciences, Kaunas, Lithuania; \\ ${ }^{2}$ Neuroscience Institute, Medical Academy, Lithuanian University of Health Sciences, Kaunas, Lithuania
}

\begin{abstract}
Background: Pituitary adenoma (PA) is a benign tumor of parenchymal cells in the adenohypophysis, and it's development is strongly associated with genetic factors.This study aim was to find whether TBX15 rs98422, DNM3 rs1011731, RAD51B rs8017304, and rs2588809 single nucleotide polymorphisms can be associated with pituitary adenoma. While the TBX15 gene belongs to the T-box family of genes and is a transcription factor involved in many developmental processes, the DNM3 encodes a protein that is a member of the dynamin family with mechanochemical properties involved in actin-membrane processes, predominantly in membrane budding, and the RAD51B gene plays a significant role in homologous recombination in DNA repair for genome stability. Materials and Methods: The study enrolled 113 patients with pituitary adenoma and 283 healthy control subjects. DNA samples were extracted and purified from peripheral blood leukocytes. Genotyping was carried out using real-time polymerase chain reaction. The results were assessed using binomial logistic regression. Results: Our study revealed that RAD51B rs2588809 TT genotype could be associated with PA development in the codominant $(O R=6.833 ; 95 \% C I=2.557-18.262 ; p<0.001)$ and recessive $(O R=7.066 ; 95 \% \quad C I=2.667-18.722 ; p<0.001)$ models. The same results were observed in females but not in males and PA without recurrence, while in PA with recurrence, no statistically significant results were obtained.
\end{abstract}

This article is freely accessible online.

Correspondence to: Alvita Vilkeviciute, Laboratory of Ophthalmology, Neuroscience Institute, Lithuanian University of Health Sciences, Eiveniu st. 2, Kaunas, LT-50161, Lithuania. Tel: +37 062424461, e-mail: alvita.vilkeviciute@1smuni.lt

Key Words: Pituitary adenoma, prolactinoma, TBX15, DNM3, RAD51B, gene polymorphisms.
Conclusion: RAD51B rs2588809 TT genotype may increase the odds of PA development in women; it may also be associated with non-recurrent PA development.

Pituitary adenoma (PA) is an intracranial tumor localized in the bone cavity (sella turcica) surrounded by multiple neural, vascular, endocrine, and bone structures, which further may contribute to an assortment of tumor types (1-7). PA accounts for approximately 15 to 20 percent of primary brain tumors with a prevalence of 77.6-97.6 PA cases per 100,000 individuals. Clinically significant PAs occur in one out of 1064 individuals (5-11). PA can occur insidiously - most patients do not realize they have it until specifically investigated. This tumor can manifest in two ways: an endocrine imbalance or pressure on the surrounding structures. The latter is the most common form of macroadenoma manifestation (12). Six to ten percent of all PAs expand into the cavernous sinus $(13,14)$. The optic chiasm is directly above the pituitary gland, so a prolonged compression of the chiasm can cause primary optic nerve atrophy and result in visual function defects, such as decreased visual acuity and visual field defects or impaired color vision (15). The earlier the tumor is diagnosed, the more likely it is to be removed and the visual function to be preserved. Endocrine changes may be due to the overexpression of tumor hormones or hypoexpression, when the tumor compresses the pituitary gland (16).

The etiology and pathogenesis of PA are complex and still poorly understood. PA represents a heterogeneous disease whose pathogenesis is a multifactorial process that involves both environmental and genetic factors. Therefore, a better understanding of the PA pathogenesis requires a comprehensive research of this disease's biological and genetic markers. Plenty of possible molecular markers, as well as intelrleukin 9 variant rs1859430, which might be incorporated in the tumorogenesis of PAs, are currently under investigation (17). Recent studies focus on genetic 
Table I. Characteristics of study subjects.

\begin{tabular}{lccc}
\hline Characteristics & $\begin{array}{c}\text { Subjects with PA } \\
\text { (group I) } \\
\mathrm{n}=113\end{array}$ & $\begin{array}{c}\text { Control group } \\
\text { (group II) } \\
\mathrm{n}=283\end{array}$ & $p$-Value \\
\hline Men, n (\%) & $45(39.8)$ & $100(35.3)$ & 0.438 \\
Women, n (\%) & $68(60.2)$ & $183(64.7)$ & 0.426 \\
Age, median (IQR) & $54(22.5)$ & $55.5(27)$ & \\
\hline
\end{tabular}

markers for cancer development, so we aimed to elucidate the role of four TXB15, DNM3 and RAD51B single nucleotide variants in PA development. The elevated genes has been reported in a variety of cancers, including prostate, ovarian cancers. However, the data regarding TBX15, DNM3 and $R A D 51 B$ genes and PA is still lacking (18-20).

$T B X 15$, a T-box family member, is possibly involved in cancer cell transformation because of its antiapoptotic function (18). It also is known that T-box genes are involved in in carcinogenesis (21-23). TBX15 is associated with prostate (24), thyroid cancer $(19,25,26)$, ovarian carcinoma (20).

The other marker dynamin 3 (DNM3) is a candidate tumor suppressor gene. This gene encodes a member of the dynamin family, which possesses mechanochemical properties to tabulate and sever membranes (27). However, few reports describe the relationship between DNM3 and malignant diseases $(28,29)$. DNM3 has been found mainly in the brain (at a lower level than DNM1) and testicles, and less frequently in the lungs and heart (30). The importance of the DNM3 gene has been investigated in gliomas $(31,32)$, hepatocellular carcinoma (33-35), colon cancer (36), and papillary thyroid carcinoma (37). Few studies have investigated the association between DNM3 and hepatocellular carcinoma, breast cancer, T-cell lymphoma, colon cancer (28-30, 33-34, 38, 39). Additionally, the importance of DNM3 was investigated in brain tumors glioblastomas (31-32).

RAD51B plays a role in homologous DNA pairing and strand exchange in DNA double-strand break repair $(38,40)$. The importance of RAD51B has previously been investigated in the breast, ovarian, lung cancer and uterine leiomyomas (31, 41-43). Also, some studies have been carried out to look for the possible association between the RAD51 gene variants and pancreatic (44-47), prostate cancer $(48,49)$, malignant melanoma (50), colorectal adenocarcinoma (51), endometrial cancer (52), soft tissue sarcoma (53) and glioblastoma (54).

Our study aimed to determine associations between TBX15 rs98422, DNM3 rs1011731, RAD51B rs8017304, rs2588809 single nucleotide polymorphisms and pituitary adenoma invasiveness, development, and recurrence.

These findings support the hypothesised role of TBX15, DNM3 and RAD 51 as tumour promoters. Based on the TBX15, DNM3 and RAD51B associations with cancerous processes we selected four widely described SNPs located in these genes. According to the dbSNP database (https://www. ncbi.nlm.nih.gov/snp/) the minor allele frequencies of these intronic variants (TBX15 rs984222, DNM3 rs1011731, $R A D 51 B$ rs8017304, rs2588809) are more than 0.1 in the Europe population, and none of these variants have been studied with PA development, invasiveness, PA activity and recurrence. The aim of the present study was to determine these associations.

\section{Materials and Methods}

Patients and selection. This study was carried out at the Department of Ophthalmology, Hospital of Lithuanian University of Health Sciences and Laboratory of Ophthalmology, Neuroscience Institute, Lithuanian University of Health Sciences. The Ethics Committee for Biomedical Research at Lithuanian University of Health Sciences (LUHS) approved the study (number BE-2-47). All subjects provided written informed consent under the Declaration of Helsinki. Based on our inclusion and exclusion criteria (55), two groups were formed in the study: the PA group $(n=113)$ and the control group $(n=283)$.

Evaluation of PA hormonal activity, invasiveness, recurrence and DNA extraction and genotyping. The analysis of all pituitary adenomas was based on histopathological findings of PA and hormone levels in the blood serum before surgery. All PA subjects were categorized into two groups - active and inactive PA (56).

Since some of the subjects had already had surgery in recent years, we categorized them by recurrence of pituitary adenoma into two groups - PA with and without recurrence.

Pituitary adenoma recurrence was diagnosed when enlargement of a residual tumor or a new growth was documented on follow-up magnetic resonance imaging (MRI) after surgical resection during the period of this study. The residual tumor was considered stable if there no signs of tumor progression on follow-up MRI. Most prolactinomas were surgically treated because of the remaining pressure effects of surrounding structures or ineffective medical treatment.

PA invasiveness has been described previously (55). The suprasellar extension and sphenoid sinus invasion by PA were classified according to the Hardy classification modified by Wilson, and the degree of suprasellar and parasellar extensions was graded as stages A-E. The degree of sellar floor erosion was graded as grades I-IV. Grade III shows localized sellar perforation, and grade IV shows diffuse destruction of sellar floor, which are the signs of invasive PA. The Knosp classification system was used to quantify the invasion of the cavernous sinus. Grade 3 and 4 pituitary tumors were considered to be invasive.

DNA was extracted from $200 \mu \mathrm{L}$ venous blood (white blood cells) using the silica-based membrane technology utilizing a genomic DNA extraction kit (GeneJET Genomic DNA Purification Kit, Thermo Scientific, MA, USA), according to the manufacturer's recommendations. The genotyping of TBX15 rs984222, DNM3 rs 1011731, RAD51B rs8017304 and rs2588809 was carried out using the real-time PCR. SNPs were genotyped on the Step One Plus real-time PCR system (Applied Biosystems, Foster City, CA, USA). The TaqMan ${ }^{\circledR}$ SNP genotyping assays (Thermo Scientific) for all SNPs were performed according to the manufacturer's protocol. The Allelic Discrimination program was used during the 
Juknyte et al: TBX15, DNM3, RAD51B Gene Variants in Pituitary Adenoma

Table II. TBX15 rs984222, DNM3 rs1011731, RAD51B rs8017304 and $R A D 51 B$ rs2588809 genotype and allele frequencies in the PA patient and control groups.

\begin{tabular}{|c|c|c|c|c|}
\hline \multirow[t]{2}{*}{ SNP } & \multirow{2}{*}{$\begin{array}{l}\text { Genotype/ } \\
\text { allele }\end{array}$} & \multicolumn{2}{|c|}{ Group } & \multirow[t]{2}{*}{$p$-Value } \\
\hline & & $\begin{array}{c}\text { Control group } \\
\mathrm{n}=283 \\
\mathrm{n}(\%)\end{array}$ & $\begin{array}{c}\text { PA group } \\
\mathrm{n}=113 \\
\mathrm{n}(\%)\end{array}$ & \\
\hline \multirow{8}{*}{$\begin{array}{l}\text { TBX15 } \\
\text { rs } 984222\end{array}$} & Genotype & & & \\
\hline & $\mathrm{G} / \mathrm{G}$ & $141(49.8)$ & 65 (57.5) & \\
\hline & $\mathrm{G} / \mathrm{C}$ & $120(42.4)$ & $42(37.2)$ & 0.341 \\
\hline & $\mathrm{C} / \mathrm{C}$ & $22(7.8)$ & $6(5.3)$ & \\
\hline & In total & $283(100)$ & $113(100)$ & \\
\hline & Allele & & & \\
\hline & G & $402(71.02)$ & $172(76.11)$ & 0.148 \\
\hline & $\mathrm{C}$ & $164(28.98)$ & $54(23.89)$ & \\
\hline \multirow{8}{*}{$\begin{array}{l}\text { DNM3 } \\
\text { rs1011731 }\end{array}$} & Genotype & & & \\
\hline & $\mathrm{A} / \mathrm{A}$ & $90(31.8)$ & $34(30.1)$ & \\
\hline & $\mathrm{G} / \mathrm{A}$ & $142(50.2)$ & $57(50.4)$ & 0.919 \\
\hline & $\mathrm{G} / \mathrm{G}$ & $51(18.0)$ & $22(19.5)$ & \\
\hline & In total & $283(100)$ & $113(100)$ & \\
\hline & Allele & & & \\
\hline & G & $322(56.89)$ & $125(55.31)$ & 0.685 \\
\hline & A & $244(43.11)$ & $101(44.69)$ & \\
\hline \multirow{8}{*}{$\begin{array}{l}R A D 51 B \\
\text { rs8017304 }\end{array}$} & Genotype & & & \\
\hline & AA & $130(45.94)$ & $49(43.36)$ & \\
\hline & $\mathrm{AG}$ & $116(40.98)$ & $52(46.02)$ & 0.609 \\
\hline & GG & $37(13.08)$ & $12(10.62)$ & \\
\hline & In total & $283(100)$ & $113(100)$ & \\
\hline & Allele & & & \\
\hline & A & $376(66.43)$ & $150(66.37)$ & 0.987 \\
\hline & G & $190(33.57)$ & $76(33.63)$ & \\
\hline$R A D 51 B$ & Genotype & & & \\
\hline \multirow[t]{7}{*}{ rs 2588809} & $\mathrm{CC}$ & $198(69.96)$ & $74(65.49)$ & \\
\hline & $\mathrm{CT}$ & $70(24.74)$ & $24(21.24)$ & 0.024 \\
\hline & TT & $15(5.30)$ & $15(13.27)$ & \\
\hline & In total & $283(100)$ & $113(100)$ & \\
\hline & Allele & & & \\
\hline & $\mathrm{C}$ & $466(82.33)$ & $172(76.12)$ & 0.045 \\
\hline & $\mathrm{T}$ & $100(17.67)$ & $54(23.88)$ & \\
\hline
\end{tabular}

PA: Pituitary adenoma; $p$-Value: Bonferroni corrected level of significance, differences are considered statistically significant when $p<0.05 / 4$.

real-time PCR. The program determined individual genotypes according to the fluorescence intensity rate of different detectors (VIC and FAM).

Statistical analysis. The age of study participants was presented as the median and interquartile range (IQR). It was compared between both study groups using the nonparametric Mann-Whitney $U$-test. All categorical variables of TBX15 rs98422, DNM3 rs1011731, $R A D 51 B$ rs8017304 and rs2588809 genotypes and alleles were expressed as absolute numbers with percentages in brackets and compared using the Pearson's $\chi^{2}$ and Fisher's exact test (when $n<50$ ) in both groups. Binomial logistic regression analysis was performed to evaluate the genotype and allele impact on PA development and reported as odds ratios (ORs) with 95\% confidence intervals (CIs). The lowest values of the Akaike
Table III. Binary logistic regression analysis of RAD51B rs 2588809 .

\begin{tabular}{lccrcc}
\hline Model & Genotype & OR $(95 \% \mathrm{CI})$ & $p$-Value & AIC \\
\hline \multicolumn{5}{c}{$R A D 51 B$ rs 2588809} \\
Co-dominant & $\mathrm{C} / \mathrm{T}$ & $0.873(0.509 ; 1.497)$ & 0.622 & 459.716 \\
& $\mathrm{~T} / \mathrm{T}$ & $6.833(2.557 ; 18.262)$ & $<\mathbf{0 . 0 0 1}$ \\
Dominant & $\mathrm{C} / \mathrm{T}+\mathrm{T} / \mathrm{T}$ & $1.332(0.833 ; 2.129)$ & 0.232 & 474.155 \\
Recessive & $\mathrm{T} / \mathrm{T}$ & $7.066(2.667 ; 18.722)$ & $<\mathbf{0 . 0 0 1}$ & 457.963 \\
Overdominant & $\mathrm{C} / \mathrm{T}$ & $0.763(0.449 ; 1.298)$ & 0.318 & 474.546 \\
Additive & $\mathrm{T}$ & $1.627(1.135 ; 2.334)$ & $\mathbf{0 . 0 0 8}$ & 468.686 \\
\hline
\end{tabular}

OR: Odds ratio; AIC: Akaike information criterion; $p$-Value: Bonferroni corrected level of significance, differences are considered statistically significant when $p<0.05 / 4$. Significant $p$-Values are shown in bold.

information criterion (AIC) showed the best genetic models. Statistically significant differences were reported when $p<0.05$, but for multiple comparisons, the Bonferroni correction was applied with the $p<0.05 / 4$ (since we analyzed four different SNPs).

\section{Results}

A total of 396 individuals were included in the study. Two groups of subjects were formed during the study. The first one included patients with pituitary adenoma, the second included healthy subjects (control group). The characteristics of the subjects are presented in Table I. The first group consisted of 113 individuals, of whom 45 (39.8\%) were men, and $68(60.2 \%)$ were women. The median age of this group was 54 years. The control group consisted of $100(35.3 \%)$ men and $183(64.7 \%)$ women. In total, the control group consisted of 283 individuals with a median age of 55.5 years.

TBX15 rs984222, DNM3 rs1011731, RAD51B rs8017304, and RAD51B rs2588809 genotype frequencies in the pituitary adenoma and healthy population groups. Hardy Weinberg analysis was performed to compare the observed and expected frequencies of TBX15 rs984222, DNM3 rs1011731, RAD51B rs8017304, and $R A D 51 B$ rs2588809 using the $\chi^{2}$ test in the control group. The genotype distribution of the polymorphisms matched the Hardy-Weinberg equilibrium. ( $p>0.001)$ (57). TBX15 rs984222, DNM3 rs1011731, RAD51B rs8017304, and $R A D 51 B$ rs2588809 genotypes and allele frequencies did not significantly differ between the PA and control groups. The results are shownin Table II.

Binomial logistic regression analysis was performed to estimate the impact of genotypes and alleles on PA development. Binomial logistic regression analysis of RAD51 rs2588809 revealed that the TT genotype was associated with about 7-fold increased odds of PA development in the co-dominant $(\mathrm{OR}=6.833$; 95\% CI=2.557$18.262 ; p<0.001)$ and recessive $(\mathrm{OR}=7.066 ; 95 \% \mathrm{CI}=2.667$ - 
Table IV. TBX15 rs984222, DNM3 rs1011731, RAD51B rs8017304 and RAD51B rs2588809 genotype and allele frequencies in PA patients and controls by gender.

\begin{tabular}{|c|c|c|c|c|c|c|}
\hline \multirow[t]{2}{*}{ Genotype/allele } & \multicolumn{2}{|c|}{ Males } & \multirow[t]{2}{*}{$p$-Value } & \multicolumn{2}{|c|}{ Females } & \multirow[t]{2}{*}{$p$-Value } \\
\hline & $\begin{array}{c}\text { PA group } n=45 \\
n(\%)\end{array}$ & $\begin{array}{c}\text { Control group } \mathrm{n}=100 \\
\mathrm{n}(\%)\end{array}$ & & $\begin{array}{c}\text { PA group } n=68 \\
n(\%)\end{array}$ & $\begin{array}{c}\text { Control group } n=183 \\
n(\%)\end{array}$ & \\
\hline \multicolumn{7}{|c|}{ TBX15 rs984222 } \\
\hline GG & $25(55.6)$ & $45(45.0)$ & 0.499 & $40(58.8)$ & $96(52.5)$ & 0.532 \\
\hline GC & $17(37.8)$ & $47(47.0)$ & & $25(36.8)$ & $73(39.9)$ & \\
\hline $\mathrm{CC}$ & $3(6.7)$ & $8(8.0)$ & & $3(4.4)$ & $14(7.7)$ & \\
\hline \multicolumn{7}{|l|}{ Allele } \\
\hline G & $67(74.4)$ & $137(68.5)$ & 0.305 & $105(77.20)$ & $265(72.40)$ & 0.277 \\
\hline $\mathrm{C}$ & $23(25.6)$ & $63(31.5)$ & & $31(22.80)$ & $101(27.60)$ & \\
\hline \multicolumn{7}{|c|}{ DNM3 rs10111731 } \\
\hline $\mathrm{AA}$ & $12(26.7)$ & $35(35.0)$ & 0.583 & $22(32.4)$ & $55(30.1)$ & 0.923 \\
\hline AG & $25(55.6)$ & $51(51.0)$ & & $32(47.1)$ & $91(49.7)$ & \\
\hline GG & $8(17.7)$ & $14(14.0)$ & & $14(20.6)$ & $37(20.2)$ & \\
\hline \multicolumn{7}{|l|}{ Allele } \\
\hline A & $49(54.4)$ & $121(60.5)$ & 0.333 & $76(55.88)$ & $201(54.91)$ & 0.847 \\
\hline G & $41(45.6)$ & $79(39.5)$ & & $60(44.12)$ & $165(45.09)$ & \\
\hline \multicolumn{7}{|c|}{$R A D 51 B$ rs 8017304} \\
\hline AA & $19(42.22)$ & $38(38.0)$ & 0.890 & $30(44.12)$ & $92(50.27)$ & 0.340 \\
\hline AG & $19(42.22)$ & $45(45.0)$ & & $33(48.53)$ & $71(38.25)$ & \\
\hline GG & $7(15.56)$ & $17(17.0)$ & & $5(7.35)$ & $20(11.48)$ & \\
\hline \multicolumn{7}{|l|}{ Allele } \\
\hline A & $57(63.33)$ & $121(60.5)$ & 0.646 & $93(68.38)$ & $255(69.67)$ & 0.780 \\
\hline G & $33(36.67)$ & $79(39.5)$ & & $43(31.62)$ & $111(30.33)$ & \\
\hline \multicolumn{7}{|c|}{$R A D 51 B$ rs 2588809} \\
\hline $\mathrm{CC}$ & $27(60.0)$ & $75(75.0)$ & 0.179 & 47 (69.12) & $123(67.21)$ & 0.011 \\
\hline $\mathrm{CT}$ & $13(28.89)$ & $19(19.0)$ & & $11(16.18)$ & $51(27.87)$ & \\
\hline $\mathrm{TT}$ & $5(11.11)$ & $6(6.0)$ & & $10(14.7)$ & $9(4.92)$ & \\
\hline \multicolumn{7}{|l|}{ Allele } \\
\hline $\mathrm{C}$ & $67(74.44)$ & $169(84.5)$ & 0.042 & $105(77.21)$ & 297 (81.15) & 0.325 \\
\hline $\mathrm{T}$ & $23(25.56)$ & $31(15.5)$ & & $31(22.79)$ & $69(18.85)$ & \\
\hline
\end{tabular}

PA: Pituitary adenoma; $p$-Value: Bonferroni corrected level of significance, differences are considered statistically significant when $p<0.05 / 4$. Significant $p$-Values are shown in bold.

$18.722 ; p<0.001)$ models. Each copy of the T allele was associated with increased odds of PA development $(\mathrm{OR}=1.627 ; 95 \% \mathrm{CI}=1.135-2.334 ; p=0.008)$ (Table III). Analysis of TBX15 rs984222, DNM3 rs1011731, and $R A D 51 B$ rs8017304 did not show any statistically significant results (Supplementary material).

Comparison of TBX15 rs984222, DNM3 rs101173, RAD51B rs8017304, and rs2588809 polymorphisms in pituitary adenoma patients by gender. Statistical analysis was also performed to compare the TBX15 rs984222, DNM3 rs101731, and RAD51 rs8017304 genotype and allele frequencies between the patients with PA and control group subjects by their gender (Table IV). The analysis of $R A D 51 B$ rs2588809 showed a statistically significant difference in the CC, CT, and TT genotype distributions between females with PA and control females $(69.12 \%, 16.18 \%$, and $14.7 \% \mathrm{vs}$. $67.21 \%, 27.87 \%$, and $4.92 \%$, respectively, $p=0.011)$. The results are presented in Table IV.

Binominal logistic regression was performed to evaluate these polymorphisms' impact on the PA development in men and women, separately. Binominal logistic regression analysis in the women's group showed that the TT genotype was associated with 6.7-fold higher odds of PA development in 
Table V. Binary logistic regression analysis of RAD51B rs 2588809 in females.

\begin{tabular}{lcccc}
\hline Model & Genotype & OR $(95 \% \mathrm{CI})$ & $p$-Value & AIC \\
\hline \multicolumn{5}{c}{ TBX15 rs984222 } \\
\hline \multicolumn{5}{c}{ RAD51B rs 2588809} \\
Co-dominant & $\mathrm{C} / \mathrm{T}$ & $0.572(0.275 ; 1.188)$ & 0.134 & 282.117 \\
& $\mathrm{~T} / \mathrm{T}$ & $6.744(2.021 ; 22.583)$ & $\mathbf{0 . 0 0 2}$ \\
Dominant & $\mathrm{C} / \mathrm{T}+\mathrm{T} / \mathrm{T}$ & $1.013(0.554 ; 1.852)$ & 0.966 & 295.251 \\
Recessive & $\mathrm{T} / \mathrm{T}$ & $7.716(2.331 ; 25.533)$ & $\mathbf{0 . 0 0 1}$ & 282.517 \\
Overdominant & $\mathrm{C} / \mathrm{T}$ & $0.486(0.236 ; 1.000)$ & 0.050 & 291.045 \\
Additive & $\mathrm{T}$ & $1.425(0.905 ; 2.245)$ & 0.126 & 292.969 \\
\hline
\end{tabular}

OR: Odds ratio; AIC: Akaike information criterion; $p$-Value: Bonferroni corrected level of significance, differences are considered statistically significant when $p<0.05 / 4$. Significant $p$-Values are shown in bold.

the co-dominant model $(\mathrm{OR}=6.744 ; 95 \% \mathrm{CI}=2.021-22.583$; $p=0.002)$ and with 7.7-fold increased odds of PA development in the recessive model $(\mathrm{OR}=7.716$; 95\% $\mathrm{CI}=2.332-25.533$; $p=0.001)$. The results are shown in Table V. The TBX15 rs984222, DNM3 rs1011731, and RAD51B rs8017304 were not associated with female PA development (Supplementary material). Also, no statistically significant variables were found in the men's group (Supplementary material).

Association of TBX15 rs984222, DNM3 rs1011731, RAD51B rs8017304, and RAD51B rs2588809 polymorphisms with clinical and morphological features of PA. One of our study's objectives was to determine if there is a relationship between $T B X 15, D N M 3$, and $R A D 51 B$ gene polymorphisms with PA's clinical and morphological features. Comparing the distribution of genotypes and alleles of TBX15 rs984222, $D N M 3$ rs1011731, RAD51B rs8017304, and RAD51B rs 2588809 between the PA groups by recurrence and the control group, we obtained statistically significant differences in the rs2588809 CC, CT, and TT genotype distributions between PA without-recurrence patients and healthy controls $(67.03 \%, 17.58 \%$ and $15.39 \%$ vs. $69.96 \%, 24.73 \%$, and $5.31 \%$, respectively; $p=0.005$ ). The results are shown in Table VI. Regarding PA recurrence, we performed binominal logistic regression to evaluate the impact of $T B X 15$ rs984222, DNM3 rs $1011731, R A D 51 B$ rs 8017304 , and $R A D 51 B$ rs 2588809 polymorphisms on the development of PAs with and without recurrence. We found that the $R A D 15 B$ rs 2588809 TT genotype was associated with approximately 8 -fold increased odds of development of PA without recurrence in the codominant $(\mathrm{OR}=7.842 ; 95 \% \mathrm{CI}=2.890-21.277 ; p<0.001)$ and recessive model $(\mathrm{OR}=8.394 ; 95 \% \mathrm{CI}=3.122-22.571 ; p<0.001)$. Also, each $\mathrm{T}$ allele was associated with 1.7 -fold increased odds of development of PA without recurrence in the additive model $(\mathrm{OR}=1.676 ; 95 \% \mathrm{CI}=0.114-2.457 ; p=0.008)$. The data are presented in Table VII. No associations were found in the recurrent PA group (Supplementary material). The TBX15 rs984222, DNM3 rs1011731, and RAD51B rs8017304 were not associated with PA recurrence (Supplementary material).

TBX15 rs984222, DNM3 rs1011731, RAD51B rs8017304, and $R A D 51 B$ rs2588809 genotypes and allele frequencies were compared between the active and inactive PA and healthy control groups. We found that the $R A D 51 B$ rs $8017304 \mathrm{G}$ allele was detected significantly more frequently in the inactive PA group $v s$. the control group (48.13\% vs. 33.57\%; $p=0.004)$ (Table VIII).

Binominal logistic regression revealed that the $R A D 51 B$ rs2588809 TT genotype was associated with increased odds of active PA development in the codominant $(\mathrm{OR}=6.058$; 95\% CI=2.146-19.734; $p=0.001)$ and recessive $(\mathrm{OR}=7.103$; 95\% CI=2.366-21.320; $p<0.001$ ) models (Table IX). Also, the $R A D 51 B$ rs 2588809 TT genotype was associated with increased odds of inactive PA development in the codominant $(\mathrm{OR}=7.247 ; 95 \% \mathrm{CI}=2.29-22.906 ; p=0.001)$ and recessive $(\mathrm{OR}=7.260 ; 95 \% \quad \mathrm{CI}=2.260-21.840 ; p=0.001)$ models. Each T allele at rs2588809 was associated with 1.9fold increased odds of inactive PA development in the additive model $(\mathrm{OR}=1.865 ; 95 \% \mathrm{CI}=1.154-3.014 ; p=0.011)$. These data are presented in Table IX. The TBX15 rs984222, DNM3 rs1011731 and RAD51 rs8017304 were not associated with PA hormonal activity (Supplementary material).

We then compared the distribution of TBX15 rs984222, DNM3 rs1011731, RAD51 rs8017304, and rs2588809 genotypes and alleles in patients with invasive and noninvasive PAs vs. healthy controls. The RAD51B rs2588809 genotypes (CC, CT, and TT) were distributed significantly differently in patients with non-invasive PA and healthy subjects $(59.09 \%, 22.72 \%$ and $18.19 \%$ vs. $69.96 \%, 24.73 \%$, and $5.31 \%$, respectively, $p=0.008$ ) (Table $\mathrm{X}$ ). Also, the $\mathrm{T}$ allele occurred more frequently in patients with non-invasive PA than in control subjects $(29.55 \%$ vs. $17.67 \%, p=0.008)$. The results are presented in Table X.

Binominal logistic regression was performed in patients with PA by its invasiveness. It was revealed that the $R A D 51 B$ rs2588809 TT genotype was associated with about 5-fold increased odds of invasive PA in the codominant $(\mathrm{OR}=4.881$; 95\% $\mathrm{CI}=1.570-15.172 ; p=0.006)$ and recessive $(\mathrm{OR}=5.212$; 95\% CI=1.693-16.050; $p=0.004$ ) models (Table XI). Also, the $R A D 51 B$ rs 2588809 TT genotype was associated with increased odds of non-invasive PA development in the codominant $(\mathrm{OR}=10.513 ; 95 \% \mathrm{CI}=3.381-32.688 ; p<0.001)$ and recessive $(\mathrm{OR}=10.259 ; 95 \% \mathrm{CI}=3.368-31.255 ; p<0.001)$ models. Each T allele was associated with 2.2-fold increased odds of non-invasive PA development in the additive model $(\mathrm{OR}=2.222 ; 95 \% \mathrm{CI}=1.352-3.652 ; p=0.002)$. The results are shown in Table XI. The TBX15 rs984222, DNM3 rs1011731, and $R A D 51$ rs8017304 were not associated with PA invasiveness (Supplementary material). 
Table VI. TBX15 rs984222, DNM3 rs1011731, RAD51B rs8017304 and RAD51B rs2588809 genotype and allele frequencies in patients grouped by $P A$ recurrence and healthy subjects.

\begin{tabular}{|c|c|c|c|c|c|c|c|}
\hline \multirow[t]{2}{*}{ SNP } & \multirow{2}{*}{$\begin{array}{l}\text { Genotype/ } \\
\text { Allele }\end{array}$} & \multicolumn{6}{|c|}{ Frequency } \\
\hline & & $\begin{array}{c}\text { PA without } \\
\text { recurrence } n(\%) \\
n=91\end{array}$ & $\begin{array}{c}\text { Control group } \\
\mathrm{n}(\%) \\
\mathrm{n}=283\end{array}$ & $p$-Value & $\begin{array}{c}\text { PA with } \\
\text { recurrence } \mathrm{n}(\%) \\
\mathrm{n}=22\end{array}$ & $\begin{array}{l}\text { Control group } \\
n(\%) n=283\end{array}$ & $p$-Value \\
\hline \multirow{6}{*}{$\begin{array}{l}\text { TBX15 } \\
\text { rs } 984222\end{array}$} & GG & $49(53.85)$ & $141(49.82)$ & 0.786 & $15(68.18)$ & $141(49.82)$ & 0.252 \\
\hline & GC & $36(39.56)$ & $120(42.40)$ & & $6(27.27)$ & $120(42.40)$ & \\
\hline & $\mathrm{CC}$ & $6(6.59)$ & $22(7.78)$ & & $1(4.55)$ & $22(7.78)$ & \\
\hline & Allele & & & & & & \\
\hline & G & $134(73.63)$ & $402(71.02)$ & 0.498 & $36(81.82)$ & $402(71.02)$ & 0.125 \\
\hline & $\mathrm{C}$ & $48(26.37)$ & $164(28.98)$ & & $8(18.18)$ & $16428.98)$ & \\
\hline \multirow{6}{*}{$\begin{array}{l}D N M 3 \\
\text { rs } 1011731\end{array}$} & AA & $28(30.77)$ & $90(31.80)$ & 0.929 & $6(27.27)$ & $90(31.80)$ & 0.900 \\
\hline & $\mathrm{AG}$ & $45(49.45)$ & $142(50.18)$ & & $12(54.55)$ & $142(50.18)$ & \\
\hline & GG & $18(19.78)$ & $51(18.02)$ & & $4(18.18)$ & $51(18.02)$ & \\
\hline & Allele & & & & & & \\
\hline & A & $101(55.49)$ & $322(56.89)$ & 0.741 & $24(54.55)$ & $322(56.89)$ & 0.762 \\
\hline & G & $81(44.51)$ & $244(43.11)$ & & $20(45.45)$ & $244(43.11)$ & \\
\hline \multirow{6}{*}{$\begin{array}{l}R A D 51 \\
\text { rs8017304 }\end{array}$} & AA & $41(45.05)$ & $130(45.94)$ & 0.941 & $8(36.36)$ & $130(45.94)$ & 0.203 \\
\hline & $\mathrm{AG}$ & $39(42.86)$ & $116(40.99)$ & & $13(59.09)$ & $116(40.99)$ & \\
\hline & GG & $11(12.09)$ & $37(13.07)$ & & $1(4.55)$ & $37(13.07)$ & \\
\hline & Allele & & & & & & \\
\hline & A & $121(66.48)$ & $376(66.43)$ & 0.989 & $29(65.90)$ & $376(66.43)$ & 0.943 \\
\hline & G & $61(33.52)$ & $190(33.57)$ & & $15(34.09)$ & $190(33.57)$ & \\
\hline \multirow{6}{*}{$\begin{array}{l}R A D 51 B \\
\text { rs } 2588809\end{array}$} & $\mathrm{CC}$ & $61(67.03)$ & $198(69.96)$ & 0.005 & $13(59.09)$ & $198(69.96)$ & 0.484 \\
\hline & $\mathrm{CT}$ & $16(17.58)$ & $70(24.73)$ & & $8(36.36)$ & $70(24.73)$ & \\
\hline & $\mathrm{TT}$ & $14(15.39)$ & $15(5.31)$ & & $1(4.55)$ & $15(5.31)$ & \\
\hline & Allele & & & & & & \\
\hline & $\mathrm{C}$ & $138(75.82)$ & $466(82.33)$ & 0.052 & $34(77.27)$ & $466(82.33)$ & 0.401 \\
\hline & $\mathrm{T}$ & $44(25.18)$ & $100(17.67)$ & & $10(22.73)$ & $100(17.67)$ & \\
\hline
\end{tabular}

PA: Pituitary adenoma; $p$-Value: Bonferroni corrected level of significance, differences are considered statistically significant when $p<0.05 / 4$. Significant $p$-Values are shown in bold.

\section{Discussion}

Our study analyzed the TBX15 rs984222, DNM3 rs1011731, $R A D 51 B \quad$ rs8017304 and $R A D 51 B$ rs2588809 gene polymorphisms in PA patients $(n=113)$ and healthy control subjects $(n=283)$. The results were compared by gender, age, and the clinical course of the disease. Studies of these polymorphisms analyzing PA association with rs984222, rs1011731, rs8017304, and rs2588809 have not been performed yet, to the best of our knowledge.

The role of TBX family genes (TBX2 and TBX3) in oncogenic processes was associated with an increase of their expression level, as they have been found to be overexpressed in different types of cancer, including breast, cervical, ovarian, pancreatic, liver, and bladder cancer (58, 59). TBX15 hypermethylation has been evaluated in prostate and ovarian carcinomas $(19,20)$. No studies have been performed in association with any brain tumors, including PA. Our study was the first to find that the $\mathrm{C}$ allele of $T B X 15$ rs984222 polymorphism reduced PA's recurrence $(p=0.037)$.
Table VII. RAD51B rs2588809 association with PA without recurrence.

\begin{tabular}{lccrc}
\hline Model & Genotype & OR $(95 \% \mathrm{CI})$ & $p$-Value & \multirow{2}{*}{ AIC } \\
\hline Co-dominant & $\mathrm{C} / \mathrm{T}$ & $0.747(0.405 ; 1.378)$ & 0.350 & 398.342 \\
& $\mathrm{~T} / \mathrm{T}$ & $7.842(2.890 ; 21.277)$ & $<\mathbf{0 . 0 0 1}$ & \\
Dominant & $\mathrm{C} / \mathrm{T}+\mathrm{T} / \mathrm{T}$ & $1.293(0.777 ; 2.150)$ & 0.323 & 418.081 \\
Recessive & $\mathrm{T} / \mathrm{T}$ & $8.394(3.122 ; 22.571)$ & $<\mathbf{0 . 0 0 1}$ & 397.245 \\
Overdominant & $\mathrm{C} / \mathrm{T}$ & $0.637(0.349 ; 1.164)$ & 0.143 & 414.772 \\
Additive & $\mathrm{T}$ & $1.676(0.114 ; 2.457)$ & $\mathbf{0 . 0 0 8}$ & 410.252 \\
\hline
\end{tabular}

OR: Odds ratio; AIC: Akaike information criterion; $p$-Value: Bonferroni corrected level of significance, differences are considered statistically significant when $p<0.05 / 4$. Significant $p$-Values are shown in bold.

DNM3 has been shown to be involved in various malignancies (28-37). Marino et al. have reported DNM3 expression in the brain and testicles and less often in the lungs and heart (29). Inokawa et al. and Shen et al. have found that DNM3 is hypermethylated in hepatocellular cancer (HCC) (33-34). Zhang et al. have also studied the 
Table VIII. TBX15 rs984222, DNM3 rs1011731, RAD51B rs8017304 and RAD51B rs2588809 genotype and allele frequencies in patients grouped by PA hormonal activity and healthy subjects.

\begin{tabular}{|c|c|c|c|c|c|c|c|}
\hline \multirow[t]{2}{*}{ SNP } & \multirow{2}{*}{$\begin{array}{l}\text { Genotype/ } \\
\text { Allele }\end{array}$} & \multicolumn{6}{|c|}{ Frequency } \\
\hline & & $\begin{array}{l}\text { Inactive PA group } \\
\qquad \begin{array}{c}n=53 \\
n(\%)\end{array}\end{array}$ & $\begin{array}{l}\text { Control group } \\
\mathrm{n}=283 \\
\mathrm{n}(\%)\end{array}$ & $p$-Value & $\begin{array}{c}\text { Active PA group } \\
\mathrm{n}=60 \\
\mathrm{n}(\%)\end{array}$ & $\begin{array}{l}\text { Control group } \\
n=283 \\
n(\%)\end{array}$ & $p$-Value \\
\hline \multirow{6}{*}{$\begin{array}{l}\text { TBX15 } \\
\text { rs } 984222\end{array}$} & GG & $30(56.60)$ & $141(49.82)$ & 0.636 & $35(58.33)$ & $141(49.82)$ & 0.252 \\
\hline & GC & $20(37.74)$ & $120(42.40)$ & & $22(36.67)$ & $120(42.40)$ & \\
\hline & $\mathrm{CC}$ & $3(5.6)$ & $22(7.78)$ & & $3(5)$ & $22(7.78)$ & \\
\hline & Allele & & & & & & \\
\hline & $\mathrm{G}$ & $80(75.47)$ & $402(71.02)$ & 0.351 & $92(76.67)$ & $402(71.02)$ & 0.125 \\
\hline & $\mathrm{C}$ & $26(24.53)$ & $164(28.98)$ & & $28(23.33)$ & $164(28.98)$ & \\
\hline \multirow{6}{*}{$\begin{array}{l}D N M 3 \\
\text { rs } 1011731\end{array}$} & AA & $16(30.19)$ & $90(31.81)$ & 0.804 & $18(30)$ & $90(31.81)$ & 0.900 \\
\hline & AG & $29(54.72)$ & $142(50.17)$ & & $28 \quad(46.67)$ & $142(50.17)$ & \\
\hline & GG & $8(15.09)$ & $51(18.02)$ & & $14(23.33)$ & $51(18.02)$ & \\
\hline & Allele & & & & & & \\
\hline & A & $61(57.55)$ & $322(56.89)$ & & $64(53.33)$ & $322(56.89)$ & 0.762 \\
\hline & $\mathrm{G}$ & $45(42.45)$ & $244(43.11)$ & 0.900 & $56(46.67)$ & $244(43.11)$ & \\
\hline \multirow{6}{*}{$\begin{array}{l}R A D 51 B \\
\text { rs8017304 }\end{array}$} & $\mathrm{AA}$ & $24(45.28)$ & $130(45.94)$ & 0.996 & $25(41.67)$ & $130(45.94)$ & 0.358 \\
\hline & $\mathrm{AG}$ & $22(41.51)$ & $116(40.99)$ & & $30(50.0)$ & $116(40.99)$ & \\
\hline & GG & $7(13.21)$ & $37(13.07)$ & & $5(8.33)$ & $37(13.07)$ & \\
\hline & Allele & & & & & & \\
\hline & A & $55(51.87)$ & $376(66.43)$ & 0.004 & 80 (66.67) & $376(66.43)$ & 0.960 \\
\hline & $\mathrm{G}$ & $51(48.13)$ & $190(33.57)$ & & $40(33.33)$ & $190(33.57)$ & \\
\hline \multirow{6}{*}{$\begin{array}{l}R A D 51 B \\
\text { rs } 2588809\end{array}$} & $\mathrm{CC}$ & $33(62.26)$ & $198(69.96)$ & 0.098 & $41(68.33)$ & $198(69.96)$ & 0.060 \\
\hline & $\mathrm{CT}$ & $13(24.53)$ & $70(24.73)$ & & $11(18.33)$ & $70(24.73)$ & \\
\hline & $\mathrm{TT}$ & $7(13.21)$ & $15(5.31)$ & & $8(13.34)$ & $15(5.31)$ & \\
\hline & Allele & & & & & & \\
\hline & $\mathrm{C}$ & $79(74.53)$ & $466(82.33)$ & 0.059 & $93(77.5)$ & $466(82.33)$ & 0.215 \\
\hline & $\mathrm{T}$ & $27(25.47)$ & $100(17.67)$ & & $27(22.5)$ & $100(17.67)$ & \\
\hline
\end{tabular}

$p$-Value: Bonferroni corrected level of significance, differences are considered statistically significant when $p<0.05 / 4$. Significant $p$-Values are shown in bold.

Table IX. RAD51B rs2588809 associations with PA hormonal activity.

\begin{tabular}{lccrc}
\hline Model & Genotype & OR $(95 \% \mathrm{CI})$ & $p$-Value & AIC \\
\hline \multicolumn{5}{c}{$R A D 51 B$ rs 2588809} \\
\hline \multicolumn{5}{c}{ Active PA } \\
\hline Co-dominant & $\mathrm{C} / \mathrm{T}$ & $0.678(0.323 ; 1.421)$ & 0.303 & 309.171 \\
& $\mathrm{~T} / \mathrm{T}$ & $6.508(2.146 ; 19.734)$ & $\mathbf{0 . 0 0 1}$ & \\
Dominant & $\mathrm{C} / \mathrm{T}+\mathrm{T} / \mathrm{T}$ & $1.126(0.612 ; 2.074)$ & 0.702 & 319.894 \\
Recessive & $\mathrm{T} / \mathrm{T}$ & $7.103(2.366 ; 21.320)$ & $<\mathbf{0 . 0 0 1}$ & 308.292 \\
Overdominant & $\mathrm{C} / \mathrm{T}$ & $0.597(0.288 ; 1.239)$ & 0.166 & 317.966 \\
Additive & $\mathrm{T}$ & $1.513(0.949 ; 2.414)$ & 0.082 & 317.159 \\
\hline
\end{tabular}

\begin{tabular}{lcccc}
\hline Model & Genotype & OR $(95 \% \mathrm{CI})$ & $p$-Value & AIC \\
\hline \multicolumn{5}{c}{$R A D 51 B$ rs2588809 } \\
\hline \multicolumn{5}{c}{ Inactive PA } \\
\hline Co-dominant & $\mathrm{C} / \mathrm{T}$ & $1.122(0.559 ; 2.249)$ & 0.746 & 286.264 \\
& $\mathrm{~T} / \mathrm{T}$ & $7.247(2.293 ; 22.906)$ & $\mathbf{0 . 0 0 1}$ & \\
Dominant & $\mathrm{C} / \mathrm{T}+\mathrm{T} / \mathrm{T}$ & $1.593(0.862 ; 2.942)$ & 0.137 & 292.775 \\
Recessive & $\mathrm{T} / \mathrm{T}$ & $7.260(2.260 ; 21.840)$ & $\mathbf{0 . 0 0 1}$ & 284.368 \\
Overdominant & $\mathrm{C} / \mathrm{T}$ & $0.970(0.491 ; 1.917)$ & 0.931 & 294.917 \\
Additive & $\mathrm{T}$ & $1.865(1.154 ; 3.014)$ & $\mathbf{0 . 0 1 1}$ & 288.799 \\
\hline
\end{tabular}

OR: Odds ratio; AIC: Akaike information criterion; $p$-Value: Bonferroni corrected level of significance, differences are considered statistically significant when $p<0.05 / 4$. Significant $p$-Values are shown in bold.

mechanism of DNM3 in HCC (60). Teicher et al. have reported liposarcoma 1q24.3 amplifications involving DNM3 (29) while low DNM2 expression has been associated with tumor invasion and metastasis in cervix carcinoma and up- regulation of matrix metalloproteinase 2 (MMP-2) expression (61). The DNM3 gene has also been investigated as a possible molecular marker for diagnosis and gene therapy of malignant diseases (38). Yang et al. have 
Table X. TBX15 rs984222, DNM3 rs1011731, RAD51B rs8017304 and RAD51B rs2588809 genotype and allele frequencies in patients grouped by $P A$ invasiveness and healthy subjects.

\begin{tabular}{|c|c|c|c|c|c|c|c|}
\hline \multirow[t]{2}{*}{ SNP } & \multirow{2}{*}{$\begin{array}{l}\text { Genotype/ } \\
\text { Allele }\end{array}$} & \multicolumn{6}{|c|}{ Frequency } \\
\hline & & $\begin{array}{c}\text { Non-invasive PA } \\
\text { group } \mathrm{n}=44 \\
\mathrm{n}(\%)\end{array}$ & $\begin{array}{l}\text { Control group } \\
\qquad \begin{array}{c}n=283 \\
\mathrm{n}(\%)\end{array}\end{array}$ & $p$-Value & $\begin{array}{c}\text { Invasive PA } \\
\text { group } \mathrm{n}=69 \\
\mathrm{n}(\%)\end{array}$ & $\begin{array}{l}\text { Control group } \\
\qquad \begin{array}{c}n=283 \\
n(\%)\end{array}\end{array}$ & $p$-Value \\
\hline \multirow{6}{*}{$\begin{array}{l}T B X 15 \\
\text { rs984222 }\end{array}$} & GG & $26(59.09)$ & $141(49.82)$ & 0.300 & 39 (56.52) & $141(49.82)$ & 0.600 \\
\hline & GC & $17(38.64)$ & $120(42.40)$ & & $25(36.23)$ & $120(42.40)$ & \\
\hline & $\mathrm{CC}$ & $1(2.27)$ & $22(7.78)$ & & $5(7.25)$ & $22(7.78)$ & \\
\hline & Allele & & & & & & \\
\hline & $\mathrm{G}$ & $69(78.41)$ & $402(71.02)$ & 0.151 & 103 (74.64) & $402(71.02)$ & 0.398 \\
\hline & $\mathrm{C}$ & 19 (21.59) & $164(28.98)$ & & $35(25.36)$ & $164(28.98)$ & \\
\hline \multirow{6}{*}{$\begin{array}{l}D N M 3 \\
\text { rs1011731 }\end{array}$} & AA & $14(31.82)$ & $90(31.81)$ & 0.732 & $20(28.99)$ & $90(31.81)$ & 0.868 \\
\hline & AG & $20(45.45)$ & $142(50.17)$ & & $37(53.62)$ & $142(50.17)$ & \\
\hline & GG & $10(27.73)$ & $51(18.02)$ & & $12(17.39)$ & $51(18.02)$ & \\
\hline & Allele & & & & & & \\
\hline & A & $48(54.55)$ & $322(56.89)$ & 0.679 & 77 (55.79) & $322(56.89)$ & 0.816 \\
\hline & $\mathrm{G}$ & $40(45.45)$ & $244(43.11)$ & & $61(44.21)$ & $244(43.11)$ & \\
\hline \multirow{6}{*}{$\begin{array}{l}R A D 51 B \\
\text { rs8017304 }\end{array}$} & $\mathrm{AA}$ & $15(34.09)$ & $130(45.94)$ & 0.232 & $34(49.28)$ & $130(45.94)$ & 0.773 \\
\hline & $\mathrm{AG}$ & $24(54.55)$ & $116(40.99)$ & & $28(40.58)$ & $116(40.99)$ & \\
\hline & GG & $5(11.36)$ & $37(13.07)$ & & $7(10.14)$ & $37(13.07)$ & \\
\hline & Allele & & & & & & \\
\hline & A & $54(61.36)$ & $376(66.43)$ & 0.351 & $96(69.57)$ & $376(66.43)$ & 0.482 \\
\hline & $\mathrm{G}$ & $34(38.64)$ & $190(33.57)$ & & $42(30.43)$ & $190(33.57)$ & \\
\hline \multirow{6}{*}{$\begin{array}{l}R A D 51 B \\
\text { rs2588809 }\end{array}$} & $\mathrm{CC}$ & $26(59.09)$ & $198(69.96)$ & 0.008 & $48(69.47)$ & $198(69.96)$ & 0.280 \\
\hline & $\mathrm{CT}$ & $10(22.72)$ & $70(24.73)$ & & $14(20.29)$ & $70(24.73)$ & \\
\hline & $\mathrm{TT}$ & $8(18.19)$ & $15(5.31)$ & & $7(10.14)$ & $15(5.31)$ & \\
\hline & Allele & & & & & & \\
\hline & $\mathrm{C}$ & $62(70.45)$ & $466(82.33)$ & 0.008 & $110(79.71)$ & $466(82.33)$ & 0.473 \\
\hline & $\mathrm{T}$ & $26(29.55)$ & $100(17.67)$ & & $28(20.29)$ & $100(17.67)$ & \\
\hline
\end{tabular}

$p$-Value: Bonferroni corrected level of significance, differences are considered statistically significant when $p<0.05 / 4$. Significant $p$-Values are shown in bold.

Table XI. RAD51B gene rs2588809 association with PA invasiveness.

\begin{tabular}{lcccc}
\hline Model & Genotype & OR $(95 \% \mathrm{CI})$ & $p$-Value & AIC \\
\hline \multicolumn{5}{c}{$R A D 51 B$ rs 2588809} \\
\hline \multicolumn{5}{c}{ Inactive PA } \\
\hline Co-dominant & $\mathrm{C} / \mathrm{T}$ & $0.755(0.387 ; 1.473)$ & 0.410 & 343.800 \\
& $\mathrm{~T} / \mathrm{T}$ & $4.881(1.570 ; 15.172)$ & $\mathbf{0 . 0 0 6}$ & \\
Dominant & $\mathrm{C} / \mathrm{T}+\mathrm{T} / \mathrm{T}$ & $1.073(0.600 ; 1.919)$ & 0.813 & 350.311 \\
Recessive & $\mathrm{T} / \mathrm{T}$ & $5.212(1.693 ; 16.050)$ & $\mathbf{0 . 0 0 4}$ & 342.503 \\
Overdominant & $\mathrm{C} / \mathrm{T}$ & $0.693(0.358 ; 1.342)$ & 0.277 & 349.125 \\
Additive & $\mathrm{T}$ & $1.357(0.857 ; 2.148)$ & 0.193 & 348.735 \\
& &
\end{tabular}

\begin{tabular}{lccrc}
\hline Model & Genotype & OR $(95 \% \mathrm{CI})$ & $p$-Value & AIC \\
\hline \multicolumn{5}{c}{ RAD51B rs 2588809} \\
\hline \multicolumn{5}{c}{ Non-invasive PA } \\
\hline Co-dominant & $\mathrm{C} / \mathrm{T}$ & $1.095(0.503 ; 2.382)$ & 0.819 & 248.474 \\
& $\mathrm{~T} / \mathrm{T}$ & $10.513(3.381 ; 32.688)$ & $\mathbf{< 0 . 0 0 1}$ & \\
Dominant & $\mathrm{C} / \mathrm{T}+\mathrm{T} / \mathrm{T}$ & $1.820(0.945 ; 3.503)$ & 0.073 & 257.197 \\
Recessive & $\mathrm{T} / \mathrm{T}$ & $10.259(3.368 ; 31.255)$ & $\mathbf{< 0 . 0 0 1}$ & 244.526 \\
Overdominant & $\mathrm{C} / \mathrm{T}$ & $0.878(0.413 ; 1.868)$ & 0.736 & 260.187 \\
Additive & $\mathrm{T}$ & $2.222(1.352 ; 3.652)$ & $\mathbf{0 . 0 0 2}$ & 250.945 \\
\hline
\end{tabular}

OR: Odds ratio; AIC: Akaike information criterion; $p$-Value: Bonferroni corrected level of significance, differences are considered statistically significant when $p<0.05 / 4$. Significant $p$-Values are shown in bold.

discussed the importance of the DNM3 gene in gliomas. As the DNM3 gene is the target of miR-221, the overexpression of DNM3 could reverse its tumor-promoting effect (31-32). Based on these findings, we sought to examine whether a polymorphism in the DNM3 promoter could impact PA development risk. Unfortunately, in our study, we did not find any statistically significant differences analyzing DNM3 rs1011731 gene polymorphism in relation to PA. 
Concerning theother two gene polymorphisms, we found that the RAD51B rs2588809 CC genotype and the rs8017304 AG genotype might increase the probability of PA recurrence and invasiveness. Also, we proved that the $R A D 51 B$ rs 2588809 TT genotype might increase the odds of PA development in women and may be associated with PA development without recurrence. The RAD51B gene has previously been studied in other tumor types (breast, ovarian, and lung cancers $(32,41)$ but not in brain tumors, so we could not compare our results with the results of other authors.

$R A D 51 B$ has been previously evaluated as a candidate gene for breast cancer predisposition, but no mutation was detected in a study of 188 multiple-case breast cancer families (62). Previous studies have identified chromosomal rearrangements disrupting $R A D 51 B$ in benign tumors, particularly uterine leiomyomas $(42,43)$. In addition, the findings by Golmard and colleagues must be interpreted in the context of two genomewide association studies (GWAS), which identified the minor allele of single nucleotide polymorphisms in RAD51B acting as a low-risk factor for breast cancer: the rs999737 (63) and rs 1314913 (64), located in RAD51B introns 10 and 7, respectively. Results by Mengyin et al. also suggest that $R A D 51 B$ could be a candidate prognostic factor for non-small cell lung cancer patients (41).

Overall, the present study of the TBX15 rs984222, DNM3 rs1011731, $R A D 51 B$ rs8017304, and $R A D 51 B$ rs2588809 gene polymorphisms requires future replication in studies with higher sample sizes to confirm the association of $R A D 51 B$ rs2588809 with PA.

\section{Conclusion}

The $R A D 51 B$ rs2588809 TT genotype was more common in women with PA than in healthy women, and the T allele was less frequent in men with PA than in healthy men. The $R A D 51 B$ rs2588809 $\mathrm{T}$ allele increased the potential for PA invasiveness and PA activity. The likelihood of PA recurrence was reduced by the TT genotype and each T allele.

\section{Data Availability}

The genotyping data used to support the findings of this study is available from the corresponding author upon request.

\section{Supplementary Material}

Available at: https://docs.google.com/document/d/1U5Za-8j3e9mbH Eye0LJlEcwVPL1f7-uSt7HlwRpslqM/edit?usp=sharing .

\section{Conflicts of Interest}

None of the Authors has any proprietary interests or conflicts of interest related to this submission.

\section{Authors' Contributions}

Conceptualization, R.L., and B.G.; Data curation, A.V., G.G., and B.G.; Writing-Original draft preparation, I.L., G.J., and R.L; Methodology, A.V., G.G., B.G., L.K, and R.L.; Investigation, A.V., G.G., G.J., I.L., and L.K.; Validation, L.K., and R.L.; Supervision, R.L., and B.G.; Writing-Reviewing and Editing, R.L.

\section{References}

1 Mete O, Ezzat S and Asa SL: Biomarkers of aggressive pituitary adenomas. Mol Endocrinol 49(2): R69-78, 2012. PMID: 22822048. DOI: $10.1530 / J M E-12-0113$

2 Drummond JB, Ribeiro-Oliveira A Jr and Soares BS: NonFunctioning Pituitary Adenomas. 2018 Nov 28. In: Feingold KR, Anawalt B, Boyce A, Chrousos G, de Herder WW, Dungan K, Grossman A, Hershman JM, Hofland J, Kaltsas G, Koch C, Kopp P, Korbonits M, McLachlan R, Morley JE, New M, Purnell J, Singer F, Stratakis CA, Trence DL, Wilson DP, editors. Endotext [Internet]. South Dartmouth (MA): MDText.com, Inc.; 2000-. PMID: 30521182.

3 Raverot G, Jouanneau E and Trouillas J: Clinicopathological classification and molecular markers of pituitary tumours for personalized therapeutic strategies. Eur J Endocrinol 170(4): R121-132, 2014. PMID: 24431196. DOI: 10.1530/EJE-13-1031

4 Kovacs K, Horvath E and Vidal S: Classification of pituitary adenomas. J Neuro-Oncol 54(2): 121-127, 2001. PMID: 11761429. DOI: 10.1023/a:1012945129981

5 Altay T, Krisht KM and Couldwell WT: Sellar and parasellar metastatic tumors. Int J Surg Oncol 2012: 647256, 2012. PMID: 22312541. DOI: $10.1155 / 2012 / 647256$

6 Vandeva S, Jaffrain-Rea M, Daly AF, Tichomirowa M, Zacharieva $S$ and Beckers A: The genetics of pituitary adenomas. Best Pract Res Clin Endocrinol Metab 24(3): 461476, 2010. PMID: 20833337. DOI: 10.1016/j.beem.2010.03.001

7 Dworakowska D and Grossman AB: The pathophysiology of pituitary adenomas. Best Pract Res Clin Endocrinol Metab 23(5): 525-541, 2011. PMID: 19945021. DOI: 10.1016/j.beem. 2009.05.004

8 Lake MG, Krook LS and Cruz SV: Pituitary adenomas: an overview. Am Fam Physician 88(5): 319-327, 2013. PMID: 24010395.

9 Gruppetta M, Mercieca C and Vassallo J: Prevalence and incidence of pituitary adenomas: a population based study in Malta. Pituitary 16(4): 545-553, 2013. PMID: 23239049. DOI: 10.1007/s11102-012-0454-0.

10 Agustsson TT, Baldvinsdottir T, Jonasson JG, Olafsdottir E, Steinthorsdottir V, Sigurdsson G, Thorsson AV, Carroll PV, Korbonits $\mathrm{M}$ and Benediktsson R: The epidemiology of pituitary adenomas in Iceland, 1955-2012: a nationwide population-based study. Eur J Endocrinol 173(5): 655-664, 2015. PMID: 26423473. DOI: 10.1530/EJE-15-0189

11 Day PF, Loto MG, Glerean M, Picasso MF, Lovazzano S and Giunta DH: Incidence and prevalence of clinically relevant pituitary adenomas: retrospective cohort study in a Health Management Organization in Buenos Aires, Argentina. Arch Endocrinol Metab 60(6): 554-561, 2016. PMID: 27982201. DOI: 10.1590/2359-3997000000195

12 Bertolessi M, Linta L, Seufferlein T, Kleger A and Liebau S: A fresh look on T-Box factor action in early embryogenesis (T-Box 
factors in early development). Stem Cells Dev 24(16): 18331851, 2015. PMID: 25952667. DOI: 10.1089/scd.2015.0102

13 Destrieux C, Kakou MK, Velut S, Lefrancq T and Jan M: Microanatomy of the hypophyseal fossa boundaries. J Neurosurg 88: 743-752, 1998. PMID: 9525722. DOI: 10.3171/jns.1998. 88.4.0743

14 Harris FS and Rhoton AL: Anatomy of the cavernous sinus: a microsurgical study. J Neurosurg 45: 169-180, 1976. PMID: 939976. DOI: $10.3171 /$ jns.1976.45.2.0169.

15 Glebauskiene B, Liutkeviciene R, Zlatkute E, Kriauciuniene L and Zaliuniene D: Association of retinal nerve fibre layer thickness with quantitative magnetic resonance imaging data of the optic chiasm in pituitary adenoma patients. J Clin Neurosci 50: 1-6, 2018. PMID: 29398198. DOI: 10.1016/j.jocn.2018.01.005

16 Ferrante E, Ferraroni M, Castrignanò T, Menicatti L, Anagni M, Reimondo G, Del Monte P, Bernasconi D, Loli P, FaustiniFustini M, Borretta G, Terzolo M, Losa M, Morabito A, Spada A, Beck-Peccoz P and Lania AG: Non-functioning pituitary adenoma database: a useful resource to improve the clinical management of pituitary tumors. Eur J Endocrinol 155(6): 823829, 2006. PMID: 17132751. DOI: 10.1530/eje.1.02298

17 Mickevicius T, Vilkeviciute A, Glebauskiene B, Kriauciuniene L and Liutkeviciene R: Do TRIB1 and IL-9 gene polymorphisms impact the development and manifestation of pituitary adenoma? In Vivo 34(5): 2499-2505, 2020. PMID: 32871778. DOI: 10.21873/invivo.12066.

18 Arribas J, Giménez E, Marcos R and Velázquez A: Novel antiapoptotic effect of TBX15: overexpression of TBX15 reduces apoptosis in cancer cells. Apoptosis 20(10): 1338-1346, 2015. PMID: 26216026. DOI: 10.1007/s10495-015-1155-8

19 Kron K, Pethe V, Briollais L, Sadikovic B, Ozcelik H, Sunderji A, Venkateswaran V, Pinthus J, Fleshner N, van der Kwast T and Bapat B: Discovery of novel hypermethylated genes in prostate cancer using genomic CpG island microarrays. PLoS One 4(3): e4830, 2009. PMID: 19283074. DOI: 10.1371/journal. pone. 0004830

20 Gozzi G, Chelbi ST, Manni P, Alberti L, Fonda S, Saponaro S, Fabbiani L, Rivasi F, Benhattar J and Losi L: Promoter methylation and downregulated expression of the TBX15 gene in ovarian carcinoma. Oncol Lett 12(4): 2811-2819, 2016. PMID: 27698863. DOI: 10.3892/ol.2016.5019

21 Peres J, Davis E, Mowla S, Bennett DC, Li JA, Wansleben S and Prince S: The highly homologous T-box transcription factors, TBX2 and TBX3, have distinct roles in the oncogenic process. Genes Cancer 1(3): 272-282, 2010. PMID: 21779450. DOI: $10.1177 / 1947601910365160$

22 Yu J, Ma X, Cheung KF, Li X, Tian L, Wang S, Wu CW, Wu WK, He M, Wang M, Ng SS and Sung JJ: Epigenetic inactivation of T-box transcription factor 5, a novel tumor suppressor gene, is associated with colon cancer. Oncogene 29(49): 6464-74, 2010. PMID: 20802524. DOI: 10.1038/onc.2010.370

23 Papaioannou VE: The T-box gene family: emerging roles in development, stem cells and cancer. Development 141(20): 3819-3833, 2014. PMID: 25294936. DOI: 10.1242/dev.104471

24 Kron K, Liu L, Trudel D, Pethe V, Trachtenberg J, Fleshner N, Bapat $\mathrm{B}$ and van der Kwast T: Correlation of ERG expression and DNA methylation biomarkers with adverse clinicopathologic features of prostate cancer. Clin Cancer Res 18(10): 2896-2904, 2012. PMID: 22452941. DOI: 10.1158/ 1078-0432.CCR-11-2901
25 Pacifico F and Leonardi A: Role of NF-kappaB in thyroid cancer. Mol Cell Endocrinol 321(1): 29-35, 2010. PMID: 19879919. DOI: $10.1016 /$ j.mce.2009.10.010

26 Xing M: Molecular pathogenesis and mechanisms of thyroid cancer. Nat Rev Cancer 13(3): 184-199, 2013. PMID: 23429735; PMCID: DOI: $10.1038 / \mathrm{nrc} 3431$

27 Orth JD and McNiven MA: Dynamin at the actin-membrane interface. Curr Opin Cell Biol 15(1): 31-39, 2003. PMID: 12517701. DOI: 10.1016/s0955-0674(02)00010-8

28 Booken N, Gratchev A, Utikal J, Weiss C, Yu X, Qadoumi M, Schmuth M, Sepp N, Nashan D, Rass K, Tüting T, Assaf C, Dippel E, Stadler R, Klemke CD and Goerdt S: Sézary syndrome is a unique cutaneous T-cell lymphoma as identified by an expanded gene signature including diagnostic marker molecules CDO1 and DNM3. Leukemia 22(2): 393-399, 2008. PMID: 18033314. DOI: 10.1038/sj.leu.2405044

29 Teicher BA: Searching for molecular targets in sarcoma. Biochem Pharmacol 84(1): 1-10, 2012. PMID: 22387046. DOI: 10.1016/j.bcp.2012.02.009

30 Marino N, Collins JW, Shen C, Caplen NJ, Merchant AS, Gökmen-Polar Y, Goswami CP, Hoshino T, Qian Y, Sledge GW Jr. and Steeg PS: Identification and validation of genes with expression patterns inverse to multiple metastasis suppressor genes in breast cancer cell lines. Clin Exp Metastasis 31(7): 771786, 2014. PMID: 25086928. DOI: 10.1007/s10585-014-9667-0

31 Yang JK, Yang JP, Tong J, Jing SY, Fan B, Wang F, Sun GZ and Jiao BH: Exosomal miR-221 targets DNM3 to induce tumor progression and temozolomide resistance in glioma. J Neurooncol 131(2): 255-265, 2017. PMID: 27837435. DOI: 10.1007/s11060-016-2308-5

32 Yang JK, Song J, Huo HR, Zhao YL, Zhang GY, Zhao ZM, Sun GZ and Jiao BH: DNM3, p65 and p53 from exosomes represent potential clinical diagnosis markers for glioblastoma multiforme. Ther Adv Med Oncol 9(12): 741-754, 2017. PMID: 29449895. DOI: $10.1177 / 1758834017737471$

33 Inokawa Y, Nomoto S, Hishida M, Hayashi M, Kanda M, Nishikawa Y, Takeda S, Fujiwara M, Koike M, Sugimoto H, Fujii T, Nakayama G, Yamada S, Tanaka C, Kobayashi D and Kodera Y: Dynamin 3: a new candidate tumor suppressor gene in hepatocellular carcinoma detected by triple combination array analysis. Onco Targets Ther 6: 1417-1424, 2013. PMID: 24143113. DOI: $10.2147 /$ OTT.S51913

34 Shen J, Wang S, Zhang YJ, Kappil M, Wu HC, Kibriya MG, Wang Q, Jasmine F, Ahsan H, Lee PH, Yu MW, Chen CJ and Santella RM: Genome-wide DNA methylation profiles in hepatocellular carcinoma. Hepatology 55(6): 1799-1808, 2012. PMID: 22234943. DOI: 10.1002/hep.25569

$35 \mathrm{Gu}$ C, Yao J and Sun P: Dynamin 3 suppresses growth and induces apoptosis of hepatocellular carcinoma cells by activating inducible nitric oxide synthase production. Oncol Lett 13(6): 4776-4784, 2017. PMID: 28599479. DOI: 10.3892/ol.2017.6057

36 Ma Y, Guan L, Han Y, Zhou Y, Li X, Liu Y, Zhang X, Zhang W, Li X, Wang S and Lu W: siPRDX2-elevated DNM3 inhibits the proliferation and metastasis of colon cancer cells via AKT signaling pathway. Cancer Manag Res 11: 5799-5811, 2019. PMID: 31388312. DOI: 10.2147/CMAR.S193805

37 Lin S, Tan L, Luo D, Peng X, Zhu Y and Li H: Linc01278 inhibits the development of papillary thyroid carcinoma by regulating miR-376c-3p/DNM3 axis. Cancer Manag Res 11: 8557-8569, 2019. PMID: 31572010 . DOI: 10.2147/CMAR.S217886 
38 Zhang HJ, Yuan GL, Liang QL, Peng X, Cheng SA, Jiang L, Liu Q, Zhang XC, Huang Z and Zeng Y: Progress of dynamin 3 in tumors. Int J Clin Exp Med 10(11): 15060-15063, 2017.

39 Jiang L, Liang QL, Liang WM, Zhang HJ, Huang J, Yuan GL, Peng XX, Cheng SA, Huang ZG and Zhang XN: Construction of a recombinant eukaryotic expression vector containing DNM3 gene and its expression in colon cancer cells. Onco Targets Ther 11: 6665-6671, 2017. PMID: 30349300. DOI: 10.2147/OTT. S176388

40 Meindl A, Hellebrand H, Wiek C, Erven V, Wappenschmidt B, Niederacher D, Freund M, Lichtner P, Hartmann L, Schaal H, Ramser J, Honisch E, Kubisch C, Wichmann HE, Kast K, Deissler H, Engel C, Müller-Myhsok B, Neveling K, Kiechle M, Mathew CG, Schindler D, Schmutzler RK and, Hanenberg H: Germline mutations in breast and ovarian cancer pedigrees establish $R A D 51 C$ as a human cancer susceptibility gene. Nat Genet 42(5): 410-414, 2010. PMID: 20400964. DOI: 10.1038/ng.569

$41 \mathrm{Wu} \mathrm{M}$, Sheng $\mathrm{Z}$, Jiang L, Liu Z, Bi Y and Shen Y: Overexpression of RAD51B predicts a preferable prognosis for non-small cell lung cancer patients. Oncotarget 8: 91471-91480, 2017. PMID: 29207658. DOI: 10.18632/oncotarget.20676

42 Heim S, Nilbert M, Vanni R, Floderus UM, Mandahl N, Liedgren S, Lecca U and Mitelman F: A specific translocation, $\mathrm{t}(12 ; 14)(\mathrm{q} 14-15 ; \mathrm{q} 23-24)$, characterizes a subgroup of uterine leiomyomas. Cancer Genet Cytogenet 32: 13-17, 1988. PMID: 3355995. DOI: 10.1016/0165-4608(88)90305-6

43 Schoenmakers EF, Huysmans C and Van de Ven WJ: Allelic knockout of novel splice variants of human recombination repair gene RAD51B in $\mathrm{t}(12 ; 14)$ uterine leiomyomas. Cancer Res 59(1): 19-23, 1999. PMID: 9892177.

44 Nagathihalli NS and Nagaraju G: RAD51 as a potential biomarker and therapeutic target for pancreatic cancer. Biochim Biophys Acta 1816(2): 209-218, 2011. PMID: 21807066. DOI: 10.1016/j.bbcan.2011.07.004

45 Thacker J: The RAD51 gene family, genetic instability and cancer. Cancer Lett 219(2): 125-135, 2005. PMID: 15723711. DOI: $10.1016 /$ j.canlet.2004.08.018

46 Zhang X, Ma N, Yao W, Li S and Ren Z: RAD51 is a potential marker for prognosis and regulates cell proliferation in pancreatic cancer. Cancer Cell Int 19: 356, 2019. PMID: 31889908. DOI: 10.1186/s12935-019-1077-6

47 Maacke H, Jost K, Opitz S, Miska S, Yuan Y, Hasselbach L, Lüttges J, Kalthoff $\mathrm{H}$ and Stürzbecher HW: DNA repair and recombination factor Rad51 is over-expressed in human pancreatic adenocarcinoma. Oncogene 19(23): 2791-2795, 2000. PMID: 10851081. DOI: 10.1038/sj.onc.1203578

48 Nowacka-Zawisza M, Wiśnik E, Wasilewski A, Skowrońska M, Forma E, Bryś M, Różański $W$ and Krajewska WM: Polymorphisms of homologous recombination RAD51, RAD51B, XRCC2, and XRCC3 genes and the risk of prostate cancer. Anal Cell Pathol (Amst) 2015: 828646, 2015. PMID: 26339569. DOI: 10.1155/2015/828646

49 Nowacka-Zawisza M, Raszkiewicz A, Kwasiborski T, Forma E, Bryś M, Różański W and Krajewska WM: RAD51 and XRCC3 polymorphisms are associated with increased risk of prostate cancer. J Oncol 2019: 2976373, 2019. PMID: 31186630. DOI: $10.1155 / 2019 / 2976373$

50 Krumm A, Barckhausen C, Kücük P, Tomaszowski KH, Loquai C, Fahrer J, Krämer OH, Kaina B and Roos WP: Enhanced histone deacetylase activity in malignant melanoma provokes
RAD51 and FANCD2-triggered drug resistance. Cancer Res 76(10): 3067-3077, 2016. PMID: 26980768. DOI: 10.1158/ 0008-5472.CAN-15-2680

51 Tennstedt P, Fresow R, Simon R, Marx A, Terracciano L, Petersen C, Sauter G, Dikomey E and Borgmann K: RAD51 overexpression is a negative prognostic marker for colorectal adenocarcinoma. Int J Cancer 132(9): 2118-2126, 2013. PMID: 23065657. DOI: $10.1002 /$ ijc. 27907

52 Michalska MM, Samulak D, Romanowicz H and Smolarz B: Association of polymorphisms in the 5' untranslated region of RAD51 gene with risk of endometrial cancer in the Polish population. Arch Gynecol Obstet 290(5): 985-991, 2014. PMID: 24930116. DOI: $10.1007 / \mathrm{s} 00404-014-3305-6$

53 Hannay JA, Liu J, Zhu QS, Bolshakov SV, Li L, Pisters PW, Lazar AJ, Yu D, Pollock RE and Lev D: Rad51 overexpression contributes to chemoresistance in human soft tissue sarcoma cells: a role for p53/activator protein 2 transcriptional regulation. Mol Cancer Ther 6(5): 1650-1660, 2007. PMID: 17513613. DOI: 10.1158/1535-7163.MCT-06-0636

54 Welsh JW, Ellsworth RK, Kumar R, Fjerstad K, Martinez J, Nagel RB, Eschbacher J and Stea B: Rad51 protein expression and survival in patients with glioblastoma multiforme. Int $\mathrm{J}$ Radiat Oncol Biol Phys 74(4): 1251-1255, 2009. PMID: 19545791. DOI: 10.1016/j.ijrobp.2009.03.018

55 Sidaraite A, Liutkeviciene R, Glebauskiene B, Vilkeviciute A and Kriauciuniene L: Associations of cholesteryl ester transfer protein (CETP) gene variants with pituitary adenoma. Biomed Pap Med Fac Univ Palacky Olomouc Czech Repub 164(2): 189195, 2020. PMID: 31012439. DOI: 10.5507/bp.2019.016

56 Liutkeviciene R, Vilkeviciute A, Morkunaite G, Glebauskiene B and Kriauciuniene L: SIRT1 (rs3740051) role in pituitary adenoma development. BMC Med Genet 20(1): 185, 2019. PMID: 31747893. DOI: 10.1186/s12881-019-0892-x

57 Donaldson P, Daly A, Ermini L and Bevitt D: Genetics of Complex Disease, 1st edition. Garland Science, Taylor Francis Group, pp. 151, 2015.

58 Rowley M, Grothey E and Couch FJ: The role of Tbx 2 and Tbx 3 in mammary development and tumorigenesis. J Mammary Gland Biol Neoplasia 9: 109-118, 2004. PMID: 15300007. DOI: 10.1023/B:JOMG.0000037156.64331.3f

59 Fan W, Huang X, Chen C, Gray J and Huang T: TBX3 and its isoform $\mathrm{TBX} 3+2 \mathrm{a}$ are functionally distinctive in inhibition of senescence and are overexpressed in a subset of breast cancer cell lines. Cancer Res 64: 5132-5139, 2004. PMID: 15289316. DOI: $10.1158 / 0008-5472 . C A N-04-0615$

60 Zhang Z, Chen C, Guo W, Zheng S, Sun Z and Geng X: DNM3 attenuates hepatocellular carcinoma growth by activating p53. Med Sci Monit 22(1): 197-205, 2016. PMID: 26784388. DOI: 10.12659/msm.896545

61 Lee YY, Do IG, Park YA, Choi JJ, Song SY, Kim CJ, Kim MK, Song TJ, Park HS, Choi CH, Kim TJ, Kim BG, Lee JW and Bae DS: Low dynamin 2 expression is associated with tumor invasion and metastasis in invasive squamous cell carcinoma of cervix. Cancer Biol Ther 10(4): 329-335, 2010. PMID: 20574164. DOI: $10.4161 /$ cbt.10.4.12275

62 Johnson J, Healey S, Khanna KK and Chenevix-Trench G: Mutation analysis of RAD51L1 (RAD51B/REC2) in multiple-case, non-BRCA1/2 breast cancer families. Breast Cancer Res Treat 129: 255-263, 2011. PMID: 21533530. DOI: 10.1007/s 10549-011$1539-6$ 
63 Thomas G, Jacobs KB, Kraft P, Yeager M, Wacholder S, Cox DG, Hankinson SE, Hutchinson A, Wang Z, Yu K, Chatterjee N, Garcia-Closas M, Gonzalez-Bosquet J, Prokunina-Olsson L, Orr N, Willett WC, Colditz GA, Ziegler RG, Berg CD, Buys SS, McCarty CA, Feigelson HS, Calle EE, Thun MJ, Diver R, Prentice R, Jackson R, Kooperberg C, Chlebowski R, Lissowska J, Peplonska B, Brinton LA, Sigurdson A, Doody M, Bhatti P, Alexander BH, Buring J, Lee IM, Vatten LJ, Hveem K, Kumle M, Hayes RB, Tucker M, Gerhard DS, Fraumeni JF Jr, Hoover RN, Chanock SJ and Hunter DJ: A multistage genome-wide association study in breast cancer identifies two new risk alleles at 1p11.2 and 14q24.1 (RAD51L1). Nat Genet 41(5): 579-584, 2009. PMID: 19330030. DOI: 10.1038/ng.353

64 Orr N, Lemnrau A, Cooke R, Fletcher O, Tomczyk K, Jones M, Johnson N, Lord CJ, Mitsopoulos C, Zvelebil M, McDade SS, Buck G, Blancher C; KConFab Consortium, Trainer AH, James
PA, Bojesen SE, Bokmand S, Nevanlinna H, Mattson J, Friedman E, Laitman Y, Palli D, Masala G, Zanna I, Ottini L, Giannini G, Hollestelle A, Ouweland AM, Novaković S, Krajc M, Gago-Dominguez M, Castelao JE, Olsson H, Hedenfalk I, Easton DF, Pharoah PD, Dunning AM, Bishop DT, Neuhausen SL, Steele L, Houlston RS, Garcia-Closas M, Ashworth A and Swerdlow AJ: Genome-wide association study identifies a common variant in $R A D 51 B$ associated with male breast cancer risk. Nat Genet 44(11): 1182-1184, 2012. PMID: 23001122. DOI: $10.1038 / \mathrm{ng} .2417$

Received November 5, 2020

Revised January 7, 2021

Accepted January 11, 2021 